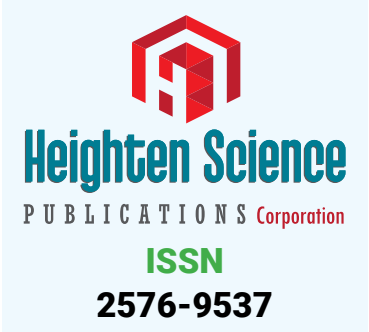

*Address for Correspondence: Abdelhamid MS, Surgery Department, Faculty of Medicine, Beni Suef, Egypt, Tel: 00201062531899; Email: mohamedsalah_2000@hotmail.com

Submitted: 01 January 2019

Approved: 11 January 2019

Published: 14 January 2019

Copyright: (c) 2019 Abdelhamid MS, et al. This is an open access article distributed under the Creative Commons Attribution License, which permits unrestricted use, distribution, and reproduction in any medium, provided the original work is properly cited

Check for updates
Research Article

\section{larogenic Bile Duct Injuries: Repairs Feasibility}

\author{
MS Abdelhamid ${ }^{1 *}$, TM Nabil', AM Rashad', SS Soliman² and \\ TM EL-Gaabary ${ }^{2}$
}

'Surgery Department, Faculty of Medicine, Beni Suef, Egypt

${ }^{2}$ Surgery Department, Faculty of Medicine, Fayum, Egypt

\section{Abstract}

Due to laparoscopic cholecystectomy there is increase in the bile duct injuries. It was $0.2 \%$ to $0.4 \%$ during open opposed to $0.6 \%$ to $0.8 \%$ during laparoscopic. Included in the study were 22 patients, 19 patients with two redo operated upon. Between Feb. 1999 to Nov2017 and 3 referral cases. The treatment options were end to end anastomosis and hepaticojejunostomy. Regarding the injuries, according to Stresberg there were $2 \mathrm{~A} .4 \mathrm{D}$ injuries with injury in the lateral aspect of the ducts, $8 \mathrm{E} 1$, with hepatic stump $>2 \mathrm{~cm}$., 5 E2 with hepatic stump $<2 \mathrm{~cm}$. The three referral cases were choledochodoudonostomy E1, and E2. They were treated with si ligation of cystic in two cases, anastomosis in seven cases. The remaining fifteen cases with hepaticojejunostomy .Conclusions: The risk is more proximally. After complex injuries diversion is the best while with simple end to end was acceptable. The insertion of stents has to be individualized according to the situations of each patients and the experience of each surgeon.

\section{Introduction}

Iatrogenic bile duct injury is a challenge for the operating surgeon [1]. Bile duct injury, is a complex and serious complication, observed with a frequency of $0.2 \%$ to $0.4 \%$. The frequency has not diminished and probably will not [2]. Less than half are recognized intraoperative, most are recognized postoperatively [3]. Many injury patterns, the first is mistaking the common bile duct for the cystic duct. The second when the distal clips are placed on the common bile duct, and the proximal clips on the cystic duct. The third is due to tenting of the common duct, the result is excision of a short segment of common duct [4].

Right hepatic ductal injury occurs with and without anatomic variation [5].

Bismuth [6] type 1 , hepatic duct stump $>2 \mathrm{~cm}$, type 2 , hepatic duct stump $<2 \mathrm{~m}$, type 3 , hepatic duct, confluence intact, type 4 , destruction of the hilar confluence, and type 5 , right sectoral duct injury. Woods et al. [7]. 1 consists of cystic duct leaks, 2 major bile duct leaks, and 3 contains the major ductal insult. Strasberg et al. [3]. A, injury to small ducts, leak in the duct of Luschka or cystic. B, sectoral duct with obstruction. C sectoral duct with bile leak, Class D lateral injury E1 stricture more than $2 \mathrm{~cm}$. E2, stricture less than $2 \mathrm{~cm}$. E3, stricture at the bifurcation E 4, insult to right and left bile ducts. Class $\mathrm{E} 5$, complete destruction. When the common hepatic or common bile duct has been ligated, simple deligation and placement of a T-tube, one limb of which goes through the area of the damage suffices [8-10].

Hepaticojejunostomy is the first option. End-to-end repair has a high failure rate [11]. Roux-en-Y jejunal loop is the best option for reconstruction [12]. Laparoscopic end-to-end choledochocholedochostomy is promising [13]. 


\section{Patients and Methods}

Between February 1999 and November 2017, 22 CBD injuries were operated upon.20 patients were females and 2 were males with mean age of 48years +_SD of 4.6. These injuries were among a total number of 2874 of cholecystectomies among them there were 564 open cholecystectomy the others were laparoscopic.

\section{The operative procedures}

A. T-tube placement, T-tube is inserted through a small separate stab in the lower segment then the two ends were reconstructed end-to-end [14].

B. Roux-en-Y hepaticojejunostomy, $70 \mathrm{~cm}$ Roux-en-Y loop of jejunum is brought up to the site of the future anastomosis. End to side is done mucosa to mucosa [15].

C. Straight stent when the ends are in the vicinity [16].

\section{Results}

22 patients were evaluated (Tables 1,2 ).

We did not mention any conservative treatment as we were assessing only repair feasibility, many patients were subjected to conservative management in the form of pig tail insertion in case of minimal leak, to others ERCP done with stenting to drain the biliary tree but not included in the current study as we are dealing with repair feasibility.

\section{Discussion}

Surgeons with experience with laparoscopic cholecystectomy have high rates of common bile duct injury $[17,18]$. Proximal bile duct is at greater risk [12].

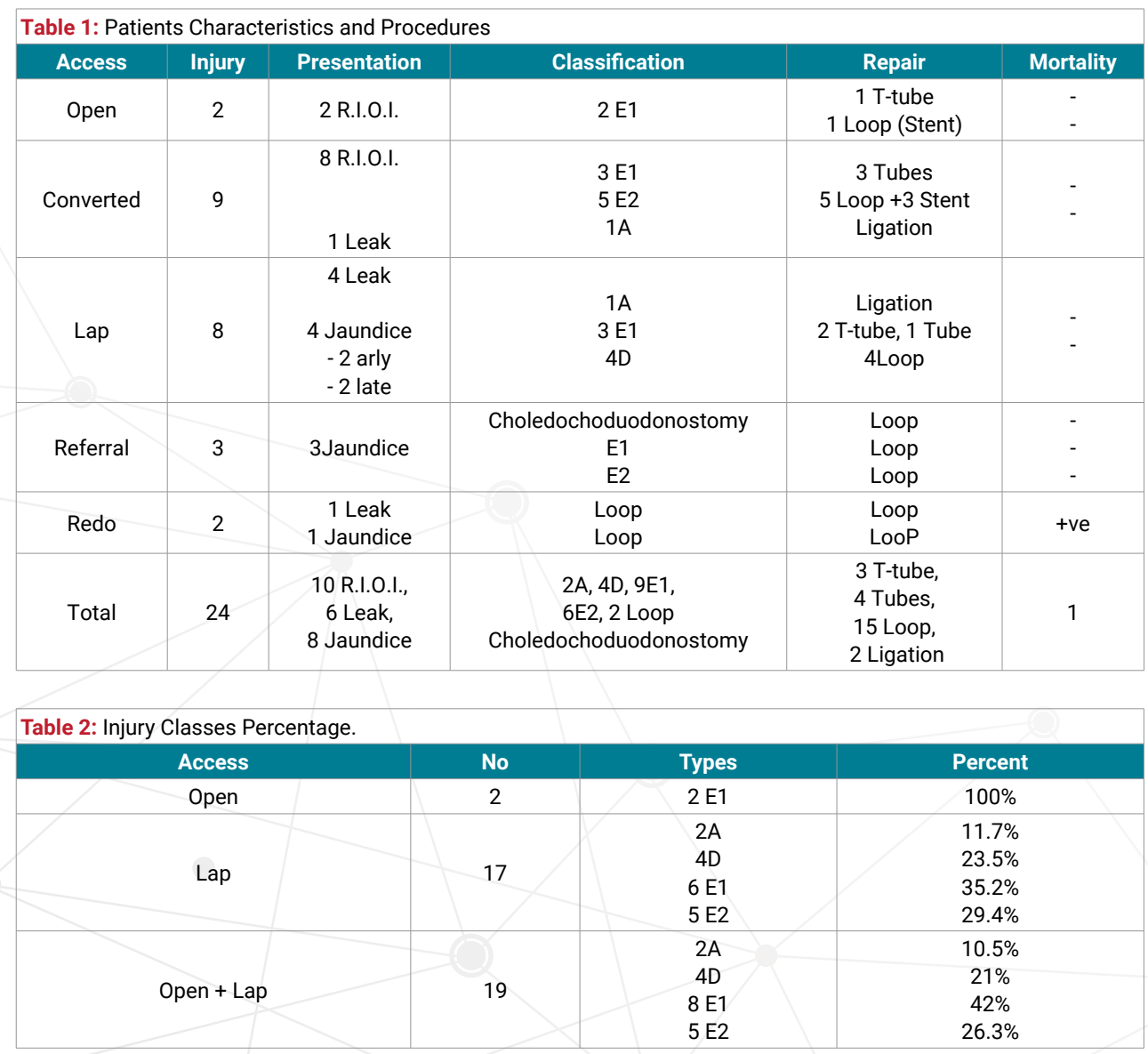


Mostly injuries were recognized intraoperatively or soon after except two cases which were thought that they were due to partial clipping, this is supported by Jarnagin and Blumgart [12], who mentioned that some injuries evolve slowly or cause partial obstruction.

We got 2A -4D - 8 E1 - 5 E2 -accounting to $10.5 \%$ A - 21\% D - 42\% E1 - $26.3 \%$ E2. In the open group E1 account to $100 \%$ of injuries, while in laparoscopic injuries E1 was $35.2 \%$ and $\mathrm{E} 2$ was $29.4 \%$ this means that proximal bile ducts are at risk for injury. The same was with Jarnagin and Blumgart [12]. In the laparoscopic cholecystectomy patients there were $11.7 \% \mathrm{~A}-23.5 \% \mathrm{D}-35.2 \% \mathrm{E} 1-29.4 \% \mathrm{E} 2$, these was aganist Murr et al. [19], who reported E1 to be 8\%, E2 27\% and E3 42\%.End to end if could be done for drainage is the best for future reconstruction [10].

Two cases with leaking stump were treated by ligation. The 4 cases with jaundice, subjected to hepaticojejunostomy.

The 8 cases with E1, 2 were in the open, 6 cases in the laparoscopic. One case in the open and two cases in lap-chole' were treated by end to end anastomosis over a T-tube, the other one in the open group was isolated right hepatic duct injury (IRHDI). That one treated with anastomosis over a stent. The other four were treated by end to end anastomosis over a straight stent avoiding the drawback of $\mathrm{T}$-tube.

E2, there were 5 cases for Roux-en-Y, 3 stented. The same reported by Mercado et al. [20]. In case of ductal dilatation stents are omitted. It is use was according to the situations.

Whenever juniors operate there were more tissue loss and more ischemia [21]. In the near future all these injuries will br managed laparoscopically [22].

These injuries should be handeled meticously to decrease morbidity and mortality [23]

\section{Conclusion}

The risk is more proximally. After complex injuries diversion is the best while with simple end to end was acceptable. The insertion of stents has to be individualized according to the situations of each patients and the experience of each surgeon.

\section{References}

1. Głuszek S, Kot M, Bałchanowski N, Matykiewicz J, Kuchinka J, et al. latrogenic bile duct injuries-clinical problems. Pol Przegl Chir. 2014; 86: 17-25. Ref.: https://goo.gl/Vqhoa1

2. Walsh RM, Henderson JM, Vogt DP, Mayes JT, Grundfest-Broniatowski S, et al. Trends in bile duct injuries from laparoscopic cholecystectomy. J Gastrointest Surg. 1998; 2: 458-462. Ref.: https://goo.gl/k7MtSu

3. Stewart L, Way LW. Bile duct injuries during laparoscopic cholecystectomy; Factors that influence the results of treatment. Arch Surg. 1995; 130: 1123-1130. Ref.: https://goo.gl/ULBVN3

4. Branum G, Schmitt C, Baillie J, Suhocki P, Baker M, et al. Management of major biliary complications after laparoscopic cholecystectomy. Ann Surg. 1993; 217: 532-541. Ref.: https://goo.gl/f55RBz

5. West Cott CJ, Pappas TN. Benign biliary strictures. In Cameron JL (ed). Current surgical therapy: st. Louis, Missouri, Mosby. 1998; 425-434.

6. Bismuth H. Postoperative stricture of the bile duct. In blumgart LH (ed). The biliary tract: Edinburgh Churchill Livingstone. 1982; 209-218.

7. Woods MS, Traverso LW, Kozorek RA. Biliary tract complications of laparoscopic cholecystectomy. Surg Endosc. 1995; 9: 1076-1080. Ref.: https://goo.gl/JhN58y

8. Strasberg $\mathrm{SM}$, Herti $\mathrm{M}$, Soper $\mathrm{Nj}$. Analysis of the problem of biliary injury during laparoscopic cholecystectomy. J Am Coll Surg. 1995; 180: 101-125. Ref.: https://goo.gl/yFfLgT

9. Solheim K, Buanes T. Bile duct injury. Int Surg. 1995; 80: 361-364. Ref.: https://goo.gl/JrKQks 
10. Gouma DJ, Obertop H. Operative bile duct injury. In Taylor I and Johnson CD (eds). Recent advances in surgery. London, Har Court Publishers Limited. 2001; 139-150.

11. Mercado MA, Orozco H, Martinez LM, del Villar APP, Tielve M, et al. Survival and quality of life after bile duct reconstruction. HPB Surg. 2000; 2: 321-324. Ref.: https://goo.gl/Emehvk

12. Jamgin WR, Blumgart LH. Operative repair of bile duct injuries involving the hepatic duct confluence. Arch Surg. 1999; 134: 769-775. Ref.: https://goo.gl/pE7NP9

13. ChoiYS, Han HS, YoonYS, LeeTG, JangJY, etal. Laparoscopicend-to-end choledochocholedochostomy for bile duct injury during laparoscopic cholecystectomy. Lap endo Adv Surg. 2006; 16: 264-266. Ref.: https://goo.gl/RC8CQ1

14. Ludwig K, Bernhardt J, steffen H, Lorenz D. Contribution of intraoperative cholangiography to incidence and outcome of common bile duct injuries during laparoscopic cholecystectomy. Surg Endosc. 2002; 16: 1098-1104. Ref.: https://goo.gl/7sdoVt

15. Lillemoe KD, Melton GB, Cameron JL, et al. Postoperative bile duct strictures: management and outcome in the 1990s. Annsurg. 2000; 232: 430-441. Ref.: https://goo.gl/J2LS1V

16. De Lédinghen V, Person B, Legoux JL, Le Sidaner A, Desaint B, et al. Prevention of biliary stent occlusion by ursodeoxycholic acid plus norfloxacin: a multicenter randomized trial. Dig Dis Sci. 2000; 45: 145-150. Ref.: https://goo.gl/WNfwrK

17. Woods MS, Traverso LW, Kozarek RA, Tsao J, Rossi RL, et al. Characteristics of biliary tract complications during laparoscopic cholecystectomy. Am J Surg. 1994; 167: 27-34. Ref.: https://goo.gl/vf3r5X

18. Flum DR, Koepsell T, Heagerty $P$, Sinanan M, Dellinger EP. Common bile duct injury during laparoscopic cholecystectomy and the use of intraoperative cholangiography. Arch Surg. 2001; 136: 1287-1292. https://goo.gl/vwNaZa

19. Murr MM, Gigot JF, Nagorney DM, Harmsen WS, Ilstrup DM, et al. Long-term results of biliary reconstruction after laparoscopic bile duct injuries. Arch Surg. 1999; 134: 604-609. Ref.: https://goo.gl/tpzf5e

20. Mercado MA, Chan C, Orozco H, Cano-Gutiérrez G, Chaparro JM, et al. To stent or not to stent bilioenteric anastomosis after iatrogenic injury. Arch Surg. 2002; 137: 60-63. Ref.: https://goo.gl/PUQACN

21. Fingerhut A, Dziri C, Garden OJ, Gouma D, Millat B, et al. ATOM, the all-inclusive, nominal EAES classification of bile duct injuries during cholecystectomy. Surg Endosc. 2013; 27: 4608-4619. Ref.: https://goo.gl/R7MsJk

22. Prasad A, De S, Mishra P, Tiwari A. Robotic assisted Roux-en- $Y$ hepaticojejunostomy in a postcholecystectomy type E2 bile duct injury. World J Gastroenterol. 2015; 21: 1703-1706. Ref.: https://goo.gl/NwQQXg

23. Barbier L, Souche R, Slim K, Ah-Soune P. Long-term consequences of bile duct injury after cholecystectomy. J Visc Surg. 2014; 151: 269-279. Ref.: https://goo.gl/ieK3yt 